\title{
Value of beryllium lymphocyte transformation tests in chronic beryllium disease and in potentially exposed
} workers

\author{
W JONES WILLIAMS, WR WILLIAMS \\ From the Welsh National School of Medicine Department of Pathology, Llandough Hospital, and the Asthma \\ Research Unit, Sully Hospital, Penarth, South Glamorgan
}

ABSTRACT The beryllium lymphocyte transformation test was performed on 16 patients with chronic beryllium disease, 10 subjects (seven patients and three young boys) who were under suspicion, and 117 healthy beryllium workers. The tests gave a positive response in all patients with definite disease and a negative response in the suspected group. Two of the healthy workers had a positive response, indicating both exposure and sensitisation. It is not known whether sensitised workers are more liable to develop disease. We consider that the test is of value in the diagnosis of beryllium disease and advocate its use in monitoring the health of potentially exposed workers.

\section{Introduction}

We have continued our studies on the value of in vitro beryllium hypersensitivity tests in the diagnosis of disease and health monitoring in potentially exposed workers. The diagnosis of chronic beryllium disease is difficult as it is often impracticable to satisfy all the diagnostic criteria. ${ }^{1}$ It is essential to obtain evidence of exposure to beryllium as consistent clinical and radiographic features and detection by biopsy of epithelioid cell granulomas do not always distinguish chronic beryllium disease from sarcoidosis. The detection of beryllium in urine or tissue is an index of exposure and not of disease. Although beryllium hypersensitivity is commonly found in association with beryllium disease, it has yet to be determined whether in healthy beryllium workers it is an index of increased susceptibility. It may be inadvisable to perform beryllium patch tests for fear of exacerbating existing disease ${ }^{2}$ or initiating hypersensitivity in non-sensitised workers. Much interest has therefore been shown in the use of in vitro hypersensitivity tests. ${ }^{3-11}$

We have previously shown ${ }^{10}$ that the beryllium lymphocyte transformation test is a more reliable method for detecting beryllium hypersensitivity than the macrophage migration inhibition test. The

Address for reprint requests: Dr W Jones Williams, Department of Pathology, Llandough Hospital, Penarth, S Glam. former was positive in all seven patients tested irrespective of steroid treatment, negative in 72 healthy beryllium workers, and reproducible on repeat testing. In contrast, the result of the macrophage migration inhibition test was positive in only four of the seven patients and was positive in four of the 72 healthy workers, and results were not reproducible. Marx and Burrell, ${ }^{9}$ however, obtained a positive response in this test in six out of seven patients. ${ }^{9} \mathrm{We}$ have also reported the optimal conditions for performing the beryllium lymphocyte transformation test. ${ }^{11}$

We now present our results for the repeat testing of the original factory population, ${ }^{6}$ additional beryllium workers, and patients, using the beryllium lymphocyte transformation test.

\section{Methods}

Details of the lymphocyte transformation technique have been described. ${ }^{11}$ Beryllium sulphate was used at a concentration $10 \mu \mathrm{mol} / \mathrm{l}$ in cultures containing human serum from the same pool of sera, taken from subjects not exposed to beryllium. Workers in factory A, factory B (first survey), and factory C were tested with $10 \%$ serum-supplemented medium. Patients, subjects under suspicion of having the disease, and factory B workers (second survey) were tested with $20 \%$ serum. The change in serum concentration was made during the course of 
the investigations as we found that the test was more sensitive with $20 \%$ serum. ${ }^{11}$ Tests were carried out on six replicate cultures and the result was expressed as a stimulation index (SI); SI = mean counts per minute of cultures with antigen $\div$ mean counts per minute of cultures without antigen. The mean counts were derived from a series of six replicates.

We consider that a stimulation index of more than 2.0 indicates hypersensitivity, on the basis of common usage and the fact that all our patients showed values in excess of this figure.

\section{Subjects}

\section{PATIENTS WITH CHRONIC BERYLLIUM DISEASE}

The group consisted of 14 men and two women aged from 38 to 68 years (mean $56 \pm 8.8$ years). Twelve had been concerned with beryllium alloy work and four with ceramic manufacture for periods ranging from three weeks to 29 years (mean $10 \pm 7 \cdot 8$ years). All had consistent clinical or radiographic features (or both) of the disease, with pulmonary lesions. Twelve of the 14 had positive histological findings. Beryllium was found in the urine of two of the eight tested and in tissue from one of three. Four of seven tested gave a positive response in the beryllium patch test. Nine were having steroid treatment at the time of testing.

\section{SUBJECTS UNDER SUSPICION OF CHRONIC BERYLLIUM DISEASE}

All the ten subjects in the second group had been potentially exposed to beryllium with the possibility of developing disease. Two were beryllium and alloy machinists. Two fitters and one slip caster worked in a ceramic factory. Two men handled only finished products, with occasional visits to a beryllium machine shop. Three young boys had been accidentally exposed to drums contaminated with beryllium oxide.

None had conclusive evidence of beryllium disease. With the exception of the three boys all had consistent evidence of respiratory disease. One patient (case 1) had a biopsy that showed pulmonary sarcoid-type granulomas. The results of urine tests were negative for beryllium in all five subjects examined (cases 1, 4, 8, 9, 10). Four were clinically diagnosed as having idiopathic pulmonary fibrosis, one sarcoidosis, and two chronic bronchitis.

An additional patient, a metallurgical chemist aged 54, with potential but not proved exposure, who had worked with various metals and alloys, was also tested. He presented with progressive dyspnoea and increasing radiographic evidence of fibrosis. Precipitin tests for a large variety of antigens (Candida; Aspergillus; budgerigar, pigeon, and chicken extracts; and Micropolyspora faeni) all gave a negative response. Lung biopsy showed interstitial fibrosis and sarcoid-type granulomas. The amount of tissue was insufficient for chemical analysis. In the absence of proved exposure and despite a negative Kveim test result the clinical diagnosis was sarcoidosis.

\section{HEALTHY BERYLLIUM FACTORY WORKERS}

Populations from three factories were examined. In factory A (53 persons) and factory B (first survey 22 persons; second survey 29 , including the 22 previously tested) workers were potentially exposed in machining pure beryllium metal and $2 \%$ beryllium alloys. Workers in factory C (35 persons) were employed in making beryllium ceramics.

In all three factories the beryllium hazard is well recognised. Protective measures include exhaust ventilation, regular air sampling, and use of protective masks and clothing. Regular clinical, radiographic, and lung function studies are performed. None of the workers showed evidence of beryllium or other diseases.

\section{Results}

PATIENTS WITH CHRONIC BERYLLIUM DISEASE

The beryllium lymphocyte transformation test using $20 \%$ serum gave a positive result in all 16 patients tested (SI 2.9-57.8) (table 1). Steroid treatment did not affect the number of positive results but depressed the responses. The average SI for the nine patients having steroids was $9.9( \pm 6.0)$, compared with $18.5( \pm 17 \cdot 7)$ for the six not receiving treatment.

Table 1 Responses to beryllium lymphocyte transformation test in patients with chronic beryllium disease

\begin{tabular}{|c|c|c|}
\hline Patient No & $C p m$ with $B e^{*}$ & $S I \dagger$ \\
\hline $\begin{array}{l}1 \ddagger \\
2 \ddagger \\
3 \ddagger \\
4 \ddagger \\
5 \ddagger \\
6 \ddagger \\
7 \\
8 \\
9 \\
10 \ddagger \\
11 \\
12 \ddagger \\
13 \ddagger \\
14 \\
15 \\
16\end{array}$ & $\begin{array}{r}5496 \\
11070 \\
7850 \\
5700 \\
36557 \\
14620 \\
13871 \\
797 \\
1826 \\
12485 \\
29689 \\
5470 \\
11668 \\
24546 \\
1667 \\
6044\end{array}$ & $\begin{array}{r}2.9 \\
3.7 \\
10 \cdot 0 \\
7.6 \\
17 \cdot 4 \\
9.3 \\
22.3 \\
3.6 \\
8 \cdot 8 \\
7 \cdot 0 \\
57 \cdot 8 \\
8 \cdot 3 \\
22.7 \\
23.2 \\
2.9 \\
11.0\end{array}$ \\
\hline \multicolumn{3}{|c|}{$\begin{array}{l}\text { *Counts per minute of cultures with beryllium. } \\
\text { †Stimulation index; this is positive for all } 16 \text { patients. } \\
\ddagger \text { Taking steroids. }\end{array}$} \\
\hline
\end{tabular}


Table 2 Responses to beryllium lymphocyte transformation test in patients suspected of having chronic beryllium disease

\begin{tabular}{|c|c|c|c|c|}
\hline Case No & Exposure & Clinical diagnosis & & $S I^{*}$ \\
\hline \multirow{9}{*}{$\begin{array}{r}1 \\
2 \\
3 \\
4 \\
5 \\
6 \\
7 \\
8 \\
9 \\
10\end{array}$} & \multirow{6}{*}{$\begin{array}{l}\text { As machinist } \\
\text { Äs fitter } \\
\text { Äs slip caster } \\
\text { From finished products }\end{array}$} & \multirow{2}{*}{\multicolumn{2}{|c|}{$\begin{array}{l}\text { Sarcoidosis } \dagger \\
\text { Idiopathic pulmonary fibrosis } \ddagger\end{array}$}} & \multirow{9}{*}{$\begin{array}{l}0.99- \\
1.25- \\
1.06- \\
0.92- \\
0.99- \\
1.11- \\
1.17- \\
1.03- \\
1.02- \\
1.04-\end{array}$} \\
\hline & & & & \\
\hline & & " $\quad$, & \multirow{7}{*}{$\begin{array}{l}" \\
"\end{array}$} & \\
\hline & & " $\quad$ " & & \\
\hline & & \multirow{2}{*}{ Chronic bronchitis } & & \\
\hline & & & & \\
\hline & Accidental $\quad$, & No disease $\quad "$, & & \\
\hline & , & , , , & & \\
\hline & $"$ & , & & \\
\hline
\end{tabular}

*Stimulation index; this was negative in all 10 cases.

$\dagger$ Taking steroids.

$\ddagger$ Later proved at necropsy to be rheumatoid lung disease.

Table 3 Responses in healthy beryllium workers in three factories

\begin{tabular}{|c|c|c|c|c|}
\hline Survey: & $\begin{array}{l}A(n=53) \\
(10 \% \text { serum })\end{array}$ & $\begin{array}{l}B(n=22) \\
\text { First survey } \\
(10 \% \text { serum })\end{array}$ & $\begin{array}{l}B(n=29) \\
\text { Second survey } \\
(20 \% \text { serum })\end{array}$ & $\begin{array}{l}C(n=35) \\
(10 \% \text { serum })\end{array}$ \\
\hline $\begin{array}{l}\text { No giving positive } \\
\text { responses }\end{array}$ & 0 & $1 \dagger$ & $2 \ddagger$ & 0 \\
\hline $\begin{array}{l}\text { No giving negative } \\
\text { responses } \\
\text { SI* }^{*}\end{array}$ & 53 & 21 & 27 & 35 \\
\hline $\begin{array}{l}\text { Mean }( \pm S D) \\
\text { Range }\end{array}$ & $\begin{array}{l}1 \cdot 06( \pm 0 \cdot 21) \\
0 \cdot 67-1 \cdot 60\end{array}$ & $\begin{array}{l}1 \cdot 06( \pm 0 \cdot 22) \\
0 \cdot 78-1 \cdot 52\end{array}$ & $\begin{array}{l}0.91( \pm 0 \cdot 27) \\
0.43-1.80\end{array}$ & $\begin{array}{l}1 \cdot 00( \pm 0 \cdot 17) \\
0 \cdot 60-1.49\end{array}$ \\
\hline
\end{tabular}

${ }^{*}$ Stimulation index.

$\dagger$ SI $=2 \cdot 2$ and $9 \cdot 1$ (test done twice).

$\ddagger S I=5.4$ (worker positive in first survey) and 13.5 (worker not tested in first survey).

\section{SUBJECTS UNDER SUSPICION OF CHRONIC BERYLLIUM} DISEASE

The result of the beryllium lymphocyte transformation test was negative in all 10 subjects, the values ranging from 0.92 to 1.25 (table 2 ). In the chemist with potential but not proved exposure the result was strongly positive $(\mathrm{SI}=34 \cdot 0)$.

\section{HEALTHY BERYLLIUM WORKERS}

The results for the healthy beryllium workers are expressed separately for $10 \%$ and $20 \%$ serum in table 3 . With $10 \%$ serum the beryllium lymphocyte transformation test gave positive responses in one worker (factory B, first survey) out of a total population (factories $\mathrm{A}, \mathrm{B}$, and $\mathrm{C}$ ) of $110(<1 \%)$. This person was positive on two occasions ( $\mathrm{SI}=2 \cdot 2$ and $9 \cdot 1$ ). With $20 \%$ serum (factory $B$, second survey) two of the 29 workers $(7 \%)$ gave a positive response. They included the one worker $(\mathrm{SI}=5.4)$ with a positive response in the first survey. The second worker was tested once only $(\mathrm{SI}=13 \cdot 5)$ and was not available for retesting; he had not been tested in the first survey.

\section{Discussion}

With optimal conditions the use of our $100 \%$ positive beryllium lymphocyte transformation test in patients with chronic beryllium disease is a considerable improvement on the results we have previously reported. Deodhar et al $^{5}$ in their earlier report found an overall positive rate of $71 \%$ (25 of 35 patients), and in a later report ${ }^{8}$ of $79 \%$ (37 of 47 patients). The tests often gave marginally positive responses and the results were not always reproducible. In contrast to our own findings, they obtained no consistent positive results in 566 healthy workers. These differences may be related to technique since in the majority of cases blast transformation was enumerated morphologically and not with tritiated thymidine.

We therefore consider that sensitisation is important in the pathogenesis of beryllium disease. The alternative view - that development of the disease is related only to dose, as sugested by Hardy ${ }^{12}$-now seems unlikely to be true.

The one positive responder with potential but not 
proved beryllium exposure illustrates the problems of the diagnosis. In view of the fact that the test has given negative results in normal people and in patients with other diseases it is tempting to label the case as one of beryllium disease. It fails, however, to meet one of the primary criteria-namely, "proved exposure" -and the diagnosis remains "unproved."

Our negative results in the three boys accidentally exposed to beryllium are of considerable value. As none has shown any evidence of disease for two years, and urine examination when they were first seen showed no beryllium, they are unlikely to have had any appreciable exposure. A positive response in the lymphocyte transformation test would have been an indication for continuing surveillance over many years as the disease may have a very long latent period-up to 25 years (unpublished observations).

We have previously shown ${ }^{10}$ that the beryllium lymphocyte transformation test using $20 \%$ serum gave a positive result in all our patients with chronic beryllium disease, but with $10 \%$ serum the rate dropped to $50 \%$. Possibly therefore we are underestimating the positive rate in the beryllium workers examined. Though the two workers with positive responses were indistinguishable from the others, the test showed that they had become sensitised to beryllium. Whether they are at increased risk of developing chronic beryllium disease remains to be seen. They and any other positive responders detected in the future will therefore be carefully monitored clinically and radiographically and by urine analysis. These two workers also illustrate a potential environmental hazard. The development of beryllium sensitisation proves an occupational exposure as it is extremely unlikely that these men would have been exposed elsewhere. Our test therefore is an indirect index of industrial hygiene. These findings would be even more useful if workers underwent a beryllium lymphocyte transformation test at the time of first employment, when it would be expected that all would give a negative result. Subsequent development of beryllium sensitisation would thus prove exposure.

We have shown, firstly, that all patients with chronic beryllium disease are sensitised to beryllium and thus the beryllium lymphocyte transformation test is of value in diagnosing the disease and, secondly, that a few healthy beryllium workers become sensitised to beryllium. Further work is required to determine whether sensitised workers are at increased risk of developing chronic beryllium disease.

We are grateful to the Health and Safety Executive for financial assistance, clinical colleagues for access to records and patients, and Miss S Nosworthy for record research. We are also grateful for the cooperation of the factories' personnel.

\section{References}

' Jones Williams W. Beryllium disease-pathology and diagnosis. J Soc Occup Med 1977;27:93-6.

2 Sneddon IB. Berylliosis: a case report. $\mathrm{Br} \mathrm{Med} J$ 은 1955;i:1448-50.

${ }^{3}$ Hanifin JM, Epstein WL, Cline MJ. "In vitro" studies of granulomatous hypersensitivity to beryllium. $J$ Invest Dermatol 1970;55:284-8.

${ }^{4}$ Jones Williams W, Grey J, Pioli EM. Diagnosis of chronic beryllium disease. $\mathrm{Br}$ Med J 1972;iv:175.

5 Deodhar SD, Barna B, van Ordstrand HS. A study of the immunological aspects of chronic berylliosis. Chest 1973;63:309-13.

- Price CD, Jones Williams W, Pugh A, Joynson DH. Role of "in vitro" tests of hypersensitivity in beryllium workers. J Clin Pathol 1977;30:24-8.

${ }^{7}$ Nishikawa S, Hirata T, Kitaichi M, Izumi I. Three year prospective study of Mantoux reactions in factory workers exposed to beryllium oxide. In: Jones Williams W, Davies BH, eds. Proceedings of eighth international conference on sarcoidosis and other granulomatous diseases. Cardiff: Alpha and Omega Press, 1980:722-7.

${ }^{8}$ Preuss OP, Deodhar SD, van Ordstrand HS. Lymphocyte transformation in beryllium workers. In: Jones Williams W, Davies BH, eds. Proceedings of eighth international conference on sarcoidosis and other granulomatous diseases. Cardiff: Alpha and Omega Press, 1980:711-4.

9 Marx JJ, Burrell R. Delayed hypersensitivity to beryllium compounds. J Immunol 1973;111:590-8.

${ }^{10}$ Williams WR, Jones Williams W. A comparison of the lymphocyte transformation (BeLT) and macrophage migration inhibition (BeMIF) tests in the detection of beryllium hypersensitivity. $J$ Clin Pathol $\mathrm{N}$ 1982;35:684-7.

$"$ Williams WR, Jones Williams W. The development of $N$ beryllium lymphocyte transformation tests in chronic $\omega$ beryllium disease. Int Arch Allergy Appl Immunol 1982;67:175-80.

12 Hardy HL. Beryllium disease: a clinical perspective. Environ Res 1980;21:1-9. 